\title{
ВПЛИВ ХРОНІЧНОЇ ГІПЕРГЛІКЕМІЇ НА РОЗВИТОК ТУБУЛОІНТЕРСТИЦІЙНОГО СИНДРОМУ ЗА ЕКСПЕРИМЕНТАЛЬНОГО ЦУКРОВОГО ДІАБЕТУ
}

\section{Вплив хронічної гіперглікемії на розвиток тубулоінтерстиційного синдрому за експериментального цукрового діабету}

\section{О. А. Оленович}

Буковинський державний медичний університет, м. Чернівці

Резюме. Діабетична хвороба нирок (ДХН) - одне з найбільш тяжких ускладнень цукрового діабету, головну роль у розвитку та прогресуванні якого відіграє нелікована чи недостатньо коригована гіперглікемія, тривалість та величина якої добре корелюють зі ступенем та швидкістю розвитку діабетичного ураження нирок. Тривала гіперглікемія запускає низку метаболічних порушень i, в решті решт, призводить до прогресуючого зниження маси діючих нефрронів.

Мета дослідження - вивчити механізми фрормування тубулоінтерстиційного синдрому на тлі хронічної алоксаніндукованої гіперглікемії.

Матеріали і методи. Дослідження проведено на 20 статевозрілих нелінійних самцях білих щурів, у 10 з яких викликали експериментальний цукровий діабет (ЕЦД) шляхом одноразового внутрішньочеревного введення розчину алоксану в дозі 160 мг/кг маси тіла, 10 щурів увійшли до контрольної групи. Через 45 діб після уведення діабетогенної речовини тварин виводили з експерименту. Статистичну обробку отриманих даних здійснювали із визначенням середньої величини, стандартних відхилень. Для оцінки вірогідності різниці між дослідними групами застосовували непараметричний ранговий критерій Манна - Уітні за алгоритмами, що реалізовані в комп'ютерній програмі «Statistica for Windows», «Version 8.0». Дослідження проводили з дотриманням положень Директиви ЄЕС № 609 (1986) та наказу МОЗ України № 690 від 23.09.2009 р. «Про заходи щодо подальшого удосконалення організаційних норм роботи 3 використанням експериментальних тварин».

Результати. Встановлено, що сосочково-кірковий та мозково-кірковий концентраційні градієнти іонів натрію істотно зростали, тоді як сосочково-мозковий натрієвий градієнт достовірно зменшувався. Аналогічні зміни стосувалися концентраційних ниркових градієнтів іонів калію. При цьому концентрація іонів натрію $і$ калію в сечі алоксандіабетичних тварин та інтенсивність їх екскреції зростала. Збільшене фрільтраційне завантаження нирок іонами натрію супроводжувалося
Influence of chronic hyperglycemia on the development of tubulointerstitial syndrome in experimental diabetes mellitus

\section{O. A. Olenovych}

Bukovinian State Medical University, Chernivtsi

e-mail: olenovych.olga@bsmu.edu.ua

Summary. Diabetic kidney disease (DKD) is one of the most serious complications of diabetes mellitus, the main role in the development and progression of which is played by untreated or insufficiently corrected hyperglycemia, the duration and magnitude of which correlate well with the degree and rate of diabetic kidney disease. Prolonged hyperglycemia triggers a number of metabolic disorders and, ultimately, leads to a progressive decrease in the mass of active nephrons.

The aim of the study - to explore the mechanisms of tubulointerstitial syndrome formation with underlying chronic alloxan-induced hyperglycemia.

Materials and Methods. The experiments were carried out on 20 white non-linear mature male rats, 10 with experimental diabetes mellitus (EDM) induced by intraperitoneal administration of alloxan at a dose of $160 \mathrm{mg} / \mathrm{kg}$ of body weight, 10 intact rats served as the control group. 45 days after administration of the diabetogenic substance, the animals were withdrawn from the experiment. Statistical processing of the obtained data was carried out with the determination of the mean value, standard deviations. To assess the probability of the difference between the experimental groups used non-parametric ranking criterion Mann-Whitney according to the algorithms implemented in the computer program "Statistica for Windows", "Version 8.0". The research was conducted in compliance with the provisions of the Council of the European Communities Directive No. 609 (1986) and the order of the Ministry of Health of Ukraine No. 690 of 23.09.2009 "On measures to further improve the organizational standards of work with the use of experimental animals".

Results. The papillary-cortical and medullarycortical concentration sodium gradients were found to be significantly increased, while the papillary-medullar sodium gradient was reliably decreased. Similar changes concerned the concentration potassium renal gradients. Meanwhile, the concentration of sodium and potassium ions in the urine of alloxandiabetic animals and the intensity of their excretion rose. Enhanced renal filtration 
збільшенням проксимальної реабсорбції іонів натрію, однак ії стандартизований за об'ємом клубочкового фрільтрату показник, так само як і дистальне надходження катіону, були меншими за показник контрольної групи. I хоча відносна реабсорбція іонів натрію залишалася практично незмінною, вона супроводжувалась значним зростанням кліренсу катіону. В пробах сечі та плазми крові визначали рівень глюкози, а також концентрацію іонів натрію та калію з наступним розрахунком (з урахуванням водного індукованого 2-годинного діурезу та кліренсу ендогенного креатиніну) показників екскреції електролітів, інтенсивності їх фрільтрації, абсолютної та відносної реабсорбції, кліренсу та концентраційного індексу, їх проксимального та дистального ниркового надходження. Вилучені після декапітації щурів нирки розшаровували на 3 частини - кіркову та мозкову речовину, сосочок нирки, у водному екстракті відповідної частини ниркової паренхіми визначали концентрацію іонів натрію та калію, обчислювали сосочково-кірковий, сосочково-мозковий та мозково-кірковий концентраційні іонні градієнти.

Висновки. Хронічна алоксаніндукована гіперглікемія спричиняє розвиток тубулоінтенстиційних порушень, прояви яких спостерігаються задовго до маніфрестації гломерулопатії. Викликане гіперперфузійно-гіперфільтраційним перевантаженням нирок виснаження реабсорбційної потужності канальцевого апарату нирок відображається як на проксимальних, так і на дистальних канальцях, та ініціює порушення прочесів реабсорбції та іоноурез. Саме розлади канальцевого надходження іонів натрію та калію, перерозподіл їх вмісту між судинним, тубулярним та інтерстиційним компартментами нирок, призводять до порушення місцевої гемодинаміки у нирках, зміни гідрофрільності та осмолярності інтерстицію, обмеження регулюючого впливу поворотно-множильної системи нирок, порушення механізмів концентрування сечі та системи регуляції водно-осмотичної рівноваги.

Ключові слова: експериментальний цукровий діабет; алоксан; концентраційні градієнти іонів натрію та калію; тубулоінтерстиційний синдром.

\section{ВСТУП}

Діабетична хвороба нирок (ДХН) - одне з найбільш тяжких ускладнень цукрового діабету, головну роль у розвитку та прогресуванні якого відіграє нелікована чи недостатньо коригована гіперглікемія, тривалість та величина якої добре корелюють зі ступенем та швидкістю розвитку діабетичного ураження нирок [1]. Тривала гіперглікемія запускає низку метаболічних порушень і, в решті решт, призводить до прогресуючого зниження маси діючих несронів [2].

Донедавна більшість авторів вважає, що визначальну роль у прогресуванні хронічної ниркової недостатності за діабетичної хвороби нирок відіграють патологічні зміни в клубочках, а тубулоінтерстиційні зміни лише супроводжують їх [2]. Останнім часом з'являється все більше доказів того, що прогресуюче зниження фрільтраційної sodium load was accompanied by an increase in proximal sodium reabsorption, but standardized in volume of glomerular filtrate, its level as well as distal cation transport level, were found to be lower as compared to the control indices. Though the relative reabsorption of sodium ions remained practically unchanged, it was accompanied by a significant elevation of cation clearance. In urine and blood plasma samples, glucose levels were determined, as well as the concentration of sodium and potassium ions, followed by calculation (taking into account waterinduced 2-hour diuresis and endogenous creatinine clearance) of electrolyte excretion, filtration intensity, absolute and relative reabsorption. index, their proximal and distal renal flow. The kidneys removed after decapitation of rats were stratified into 3 parts - cortical and cerebral substance, renal papillae, in the aqueous extract of the corresponding part of the renal parenchyma determined the concentration of sodium and potassium ions, calculated papillary-cortical, papillary-cerebral and cerebral-cortical.

Conclusions. Chronic alloxan-induced hyperglycemia causes the development of tubulointensive disorders, the manifestations of which are observed long before the manifestation of glomerulopathy. Caused by hyperperfusionhyperfiltration overload of the kidneys, the depletion of the reabsorption capacity of the tubular apparatus of the kidneys is reflected on both the proximal and distal tubules, and initiates a violation of the reabsorption processes and ionouresis. It is disorders of the tubular supply of sodium and potassium ions, redistribution of their content between the vascular, tubular and interstitial compartments of the kidneys, lead to local hemodynamics in the kidneys, changes in hydrophilicity and osmolarity of the interstitium, limiting regulatory effects of reversible multiplication system regulation of water-osmotic balance.

Key words: experimental diabetes mellitus; alloxan; concentration gradient of sodium and potassium; tubulointerstitial syndrome.

здатності нирок та наростаюча протеїнурія, котрі вважаються клінічними маркерами ДХН, корелюють, головним чином, зі ступенем тубулоінтерстиційних, а не гломерулярних ушкоджень, і більшість подій, які визначають її перебіг, відбувається саме в нирковому інтерстиції [1, 3-5].

На думку багатьох авторів, ушкодження тубулоінтерстиційної тканини (TIT) є ключовою детермінантою фрормування хронічної ниркової недостатності (ХНH) [4, 6]. Встановлено, що навіть виражене ураження клубочків не призводить до ХНH за відсутності тубулоінтерстиційних змін [6, 7]. Саме вираження фріброзу TIT вважають найточнішим предиктором незворотної втрати ниркової фрункції і прогресування ХНH $[3,8]$.

Відтак вивчення особливостей формування тубулоінтерстиційного синдрому (ТIC) - особливої фрорми
Вісник медичних і біологічних досліджень

Bulletin of Medical and Biological Research
$1(7), 2021$ 
ураження нирок, для якого характерна патологія як ниркових канальців, так і інтерстицію на рівні кіркової, мозкової речовини, ниркового сосочка 3 порушенням основних канальцевих фрункцій [9] - вимагає особливої уваги за цукрового діабету, коли поєднаний вплив прямої глюкозотоксичності та метаболічних наслідків хронічної гіперглікемії ініціює розвиток ренопатії.

Метою дослідження було вивчити механізми фрормування тубулоінтерстиційного синдрому на тлі хронічної алоксаніндукованої гіперглікемії.

\section{МАТЕРІАЛИ I МЕТОДИ}

Дослідження проведено на 20 статевозрілих нелінійних самцях білих щурів, масою 0,18-0,20 кг, яких утримували в ідентичних стандартних умовах віварію. Вплив хронічної гіперглікемії на фрормування ТIC вивчали за умов експериментального цукрового діабету (ЕЦД), котрий моделювали шляхом одноразового внутрішньочеревного введення 10 тваринам розчину алоксану (Alloxan monohydrate, «Acros Organics», Бельгія) в дозі 160 мг/кг маси тіла після попередньої 12-годинної депривації їжі при збереженому доступі до води. Через 45 діб після уведення діабетогенної речовини щурів виводили 3 експерименту. 8-ми діабетичним щурам (рівень летальності становив 20,0 \% - 2 щурів) та 10-м контрольним тваринам проводили навантаження водогінною водою в об'ємі 5 \% від маси тіла, сечу збирали упродовж 2 год, здійснювали евтаназію шляхом декапітації під легким ефрірним знеболюванням. У пробах крові визначали рівень глюкози за допомогою портативного глюкометра One Touch Ultra (LifeScan, США) та враховували в подальшому лише показники щурів зі стійкою гіперглікемією, що сягала понад 7,0 ммоль/л. У пробах сечі визначали вміст глюкози колориметричним ензиматичним методом за допомогою стандартного діагностичного набору реактивів Liquick Cor-GLUCOSE (Польща).

Подальший аналіз проб сечі та плазми крові дозволив оцінити діяльність судинно-клубочкового апарату, проксимального та дистального канальцевих відділів несрону кліренс-методом [10, 11]. Концентрацію іонів натрію та калію у пробах сечі та плазми крові визначали методом фротометрії полум'я на «ФПЛ-1» 3 наступним розрахунком (3 урахуванням водного індукованого 2-годинного діурезу та кліренсу ендогенного креатиніну) показників екскреції електролітів, інтенсивності їх фрільтрації, абсолютної та відносної реабсорбції, кліренсу та концентраційного індексу, їх проксимального та дистального нирковогонадходження. Для стандартизації показників ниркового надходження електролітів абсолютні їх величини перераховували на 100 мкл клубочкового фрільтрату (КФ) [10, 11].

3 метою оцінки іонного вмісту окремих структур ниркової паренхіми та характеру іонних кон- центраційних градієнтів, вилучені після декапітації щурів нирки відмивали від домішок крові, їх середню ділянку розшаровували на 3 частини - кіркову та мозкову речовину, сосочок нирки. Наважки виокремлених шарів ниркової тканини занурювали у 5 мл дистильованої води у флаконах 3 герметичними пробками, залишали на 24 год у холодильнику при температурі $4{ }^{\circ} \mathrm{C}$ для повної екстракції електролітів. Концентрацію іонів натрію та калію в отриманому екстракті відповідної частини ниркової паренхіми визначали методом полум'яної фротометрії та розраховували на 1 г тканини нирок. Обчислювали сосочково-кірковий, сосочково-мозковий та мозково-кірковий концентраційні градієнти іонів натрію та калію, а за їх відхиленням оцінювали характер тубулоінтерстиційного синдрому.

Статистичну обробку отриманих даних здійснювали із визначенням середньої величини, стандартних відхилень. Для оцінки вірогідності різниці між досліджними групами застосовували непараметричний ранговий критерій Манна - Уїтні за алгоритмами, що реалізовані в комп'ютерній програмі Statistica for Windows, Version 8.0 [12].

Дослідження проводили 3 дотриманням положень Директиви ЄЕС №609 (1986) та наказу МО3 України № 690 від 23.09.2009 р. «Про заходи щодо подальшого удосконалення організаційних норм роботи з використанням експериментальних тварин».

\section{РЕЗУЛЬТАТИ Й ОБГОВОРЕННЯ}

На 46-й день після введення діабетогенної речовини концентрація глюкози в крові експериментальних тварин була у 2,2 раза вищою за показник контрольної групи (p<0,001) (рис. 1), що супроводжувалося надмірним виділенням глюкози з сечею (рис. 2).

За перманентної алоксаніндукованої гіперглікемії та глюкозурії уміст натрію у кірковій речовині нирок зменшувався майже уп'ятеро (у 4,6 раза) відносно показника контролю, в нирковому сосочку - на 36 \%, дещо зростаючи (на 7,2 \%) у мозковій речовині нирок (табл. 1). Концентрація іонів калію також зменшувалася у всіх шарах ниркової паренхіми - уп'ятеро в кірковій речовині, на 33 \% у нирковому сосочку та меншою мірою - на 4,5 \% - у мозковій речовині нирок. При цьому натрій-калієвий коефріцієнт достовірно зростав для кіркового та мозкового шару нирок (на 8 та 12 \% відповідно), недостовірно зменшуючись (на 4,4 \%) - для ниркового сосочка.

Істотно зростали сосочково-кірковий (у 3 рази, p<0,001) та мозково-кірковий (у 4,9 раза, $р<0,001)$ концентраційні градієнти іонів натрію, тоді як сосочково-мозковий натрієвий градієнт достовірно зменшувався (на 39,2 \%, р<0,001) (рис. 3). Переважне накопичення іонів натрію у мозковій речовині нирок не лише слугує маркером первинного пригнічення проксимального та дистального транстубулярного надходження катіону, а й вказує на обме- 


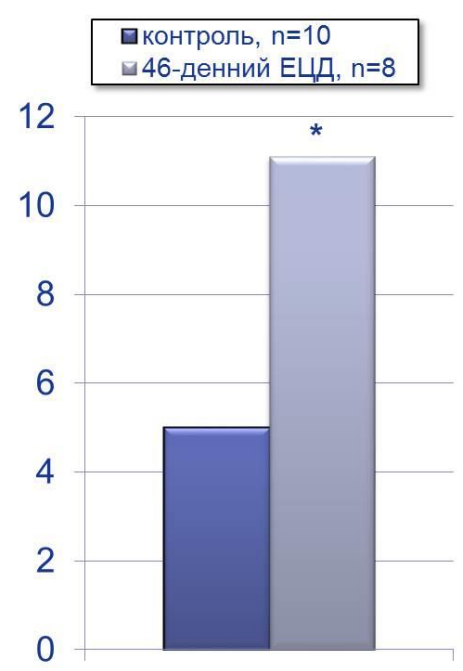

Рис. 1. Концентрація глюкози в крові (ммоль/л) щурів із 46-денним експериментальним цукровим діабетом.

Примітка. * - вірогідність розбіжності показників відносно контролю p<0,05; оцінювали міжгрупові відмінності за допомогою непараметричного критерію Манна - Уїтні.

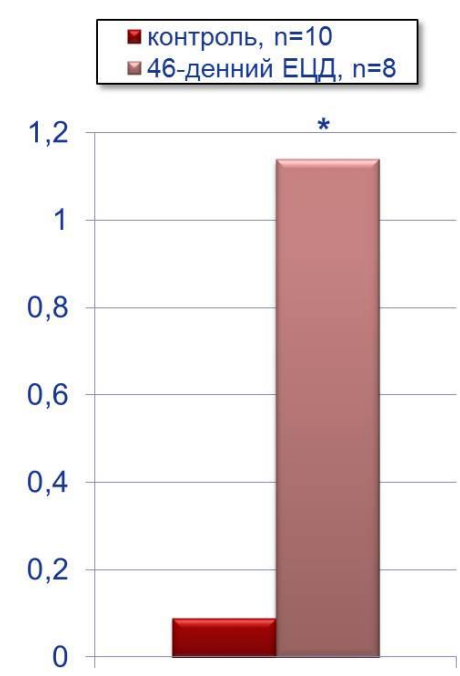

Рис. 2. Концентрація глюкози в сечі (ммоль/л) щурів із 46-денним експериментальним цукровим діабетом.

Примітка. * - вірогідність розбіжності показників відносно контролю p<0,05; оцінювали міжгрупові відмінності за допомогою непараметричного критерію Манна - Уїтні.

Таблиця 1. Динаміка змін вмісту іонів натрію та калію в різних відділах нирок у динаміці фрормування алоксаніндукованої діабетичної нефропатії

\begin{tabular}{|c|c|c|}
\hline \multirow[b]{2}{*}{ Показник } & \multicolumn{2}{|c|}{ Група, кількість тварин } \\
\hline & $\begin{array}{c}\text { контроль } \\
(\mathrm{n}=8)\end{array}$ & $\begin{array}{c}\text { 46-денний алоксановий діабет } \\
(\mathrm{n}=8)\end{array}$ \\
\hline \multicolumn{3}{|c|}{ Кіркова речовина нирок: } \\
\hline Натрій, ммоль/1 г тканини & $56,98 \pm 1,00$ & $\begin{array}{c}12,47 \pm 0,52 \\
p<0,001\end{array}$ \\
\hline Калій, ммоль/1 г тканини & $95,20 \pm 2,27$ & $\begin{array}{c}19,19 \pm 0,60 \\
p<0,001\end{array}$ \\
\hline Натрій-калієвий коефріцієнт, од. & $0,60 \pm 0,01$ & $\begin{array}{l}0,65 \pm 0,02 \\
p<0,05\end{array}$ \\
\hline \multicolumn{3}{|c|}{ Мозкова речовина нирок: } \\
\hline Натрій, ммоль/1 г тканини & $61,86 \pm 0,85$ & $\begin{array}{c}66,29 \pm 2,36 \\
p>0,1\end{array}$ \\
\hline Калій, ммоль/1 г тканини & $92,74 \pm 2,36$ & $\begin{array}{c}88,56 \pm 2,33 \\
p>0,2\end{array}$ \\
\hline Натрій-калієвий коефріцієнт, од. & $0,67 \pm 0,02$ & $\begin{array}{c}0,75 \pm 0,02 \\
p<0,05\end{array}$ \\
\hline \multicolumn{3}{|c|}{ Нирковий сосочок: } \\
\hline Натрій, ммоль/1 г тканини & $112,04 \pm 1,52$ & $\begin{array}{c}72,31 \pm 4,24 \\
p<0,001\end{array}$ \\
\hline Калій, ммоль/1 г тканини & $122,34 \pm 2,99$ & $\begin{array}{c}82,61 \pm 3,59 \\
p<0,001\end{array}$ \\
\hline Натрій-калієвий коефріцієнт, од. & $0,92 \pm 0,02$ & $\begin{array}{c}0,88 \pm 0,03 \\
p>0,1\end{array}$ \\
\hline
\end{tabular}

Примітка. Оцінку міжгрупових відмінностей здійснювали за допомогою непараметричного критерію Манна - Уїтні; р - вірогідність розбіжності показників відносно контролю.

ження регулюючого впливу поворотно-множильної системи нирок. Водночас, надходження надміру натрію до петлі Генле та перерозподіл катіону між фрільтратом та інтерстицієм підвищує осмолярність останнього і, у свою чергу, обмежує надходження іонів натрію до дистального сегмента нефрону, послаблюючи канальцево-канальцевий баланс і зменшуючи обсяг дистальної реабсорбції катіону. Крім того, за пригніченням сосочково-мозкового натрієвого градієнта можна припустити обмеження 


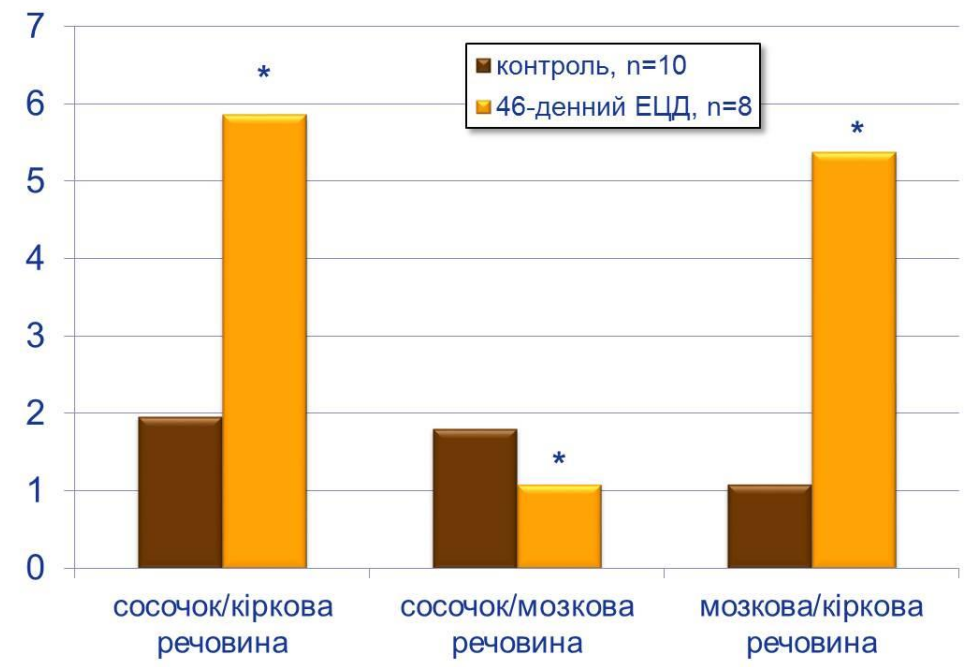

Рис. 3. Концентраційні градієнти іонів натрію (од.) у нирках щурів із 46-денним експериментальним цукровим діабетом.

Примітка. * - вірогідність розбіжності показників відносно контролю р<0,05; оцінювали міжгрупові відмінності за допомогою непараметричного критерію Манна - Уїтні.

екскреції натрію кожним окремим несрроном і вбачати причини натрійурезу в зростанні фрільтраційної фрракції катіону та перевищенні реабсорбційного потенціалу проксимального канальця.

На підтвердження такого тлумачення, сосочковокірковий та мозково-кірковий концентраційні градієнти іонів калію істотно зростали -відповідно у 3,4 ( $p<0,001)$ та 4,8 раза ( $<<0,001)$, супроводжуючись зменшенням на 30,1\% (p<0,001) сосочково-мозкового калієвого градієнта (рис. 4) і слугуючи ознакою патології інтерстицію та АДГ-залежних механізмів регуляції осмолярності сечі та, ймовірно, збереженої альдостеронзалежної секреції іонів калію як причини калійурезу.
Функціональні параметри іоновидільної діяльності нирок узгоджувалися з результатами обчислення іонних концентраційних градієнтів. Так, калійурична реакція нирок алоксан-діабетичних щурів на 46-й день експерименту була помірною - концентрація іонів калію в сечі на 17,5 \% перевищувала контрольний рівень, тоді як екскреція калію була на 32,4 \% більшою за показник контрольної групи (табл. 2). У 1,8 раза вищий, порівняно з контролем, коефріцієнт співвідношення концентрацій іонів натрію і калію в сечі свідчив на користь переважання натрійурезу.

Концентрація натрію в сечі алоксандіабетичних тварин зростала вдвічі, а екскреція катіону в

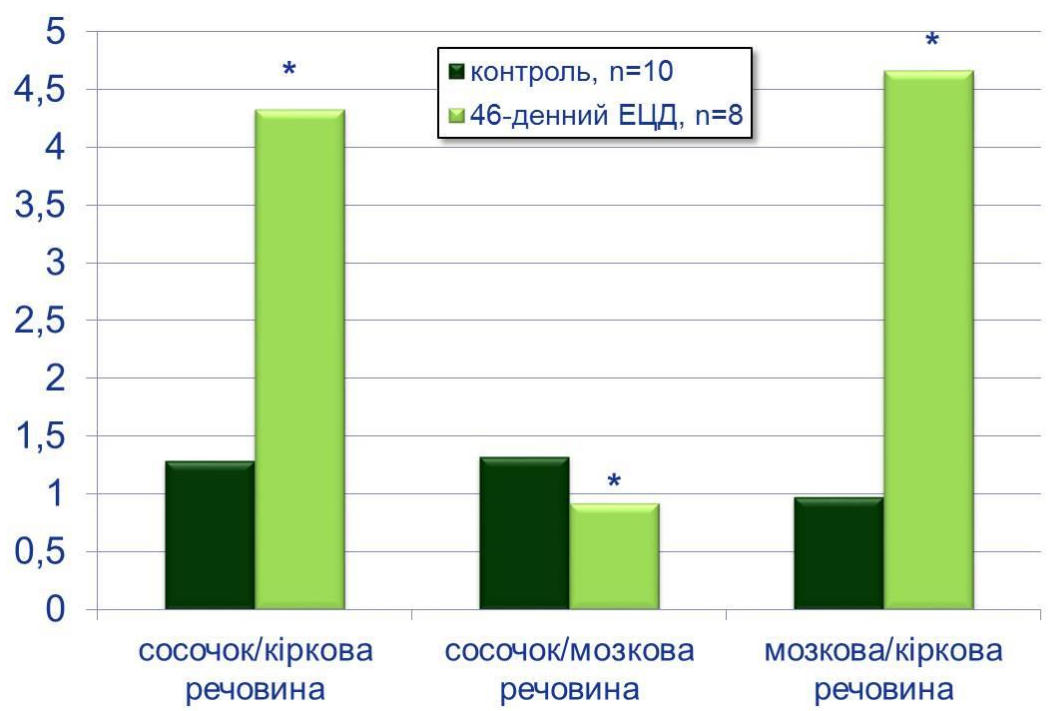

Рис. 4. Концентраційні градієнти іонів калію (од.) у нирках щурів з 46-денним експериментальним цукровим діабетом.

Примітка. * - вірогідність розбіжності показників відносно контролю р<0,05; оцінювання міжгрупових відмінностей за допомогою непараметричного критерію Манна - Уїтні. 
2,3 раза перевищувала контрольний показник, тоді як приведена до одиниці діючих нефронів виявила тенденцію до зменшення (на 36,4 \%).

3більшене у 2,6 раза фрільтраційне завантаження нирок іонами натрію закономірно супроводжувалося інтенсиорікацією абсолютного канальцевого надходження катіону. Разом з тим, зменшення реабсорбційної потужності канальцевого апарату нирок, ймовірно, сприяло втратам натрію з сечею: незважаючи на збільшення проксимальної реабсорбції іонів натрію у 2,7 раза, їі стандартизований за КФ показник виявився на 8,6 \% достовірно нижчим за контрольний рівень, а дистальне надходження катіону, в т. ч. стандартизованого за об'ємом КФ, був меншим за показник контрольної групи тварин (утричі нижчим за приведення до одиниці ультрафрільтрату) (табл. 3). Відтак хоча відносна реабсорбція іонів натрію залишалася практично незмінною, вона супроводжувалась значним зростанням кліренсу катіону (в 2,5 раза).

Таблиця 2. Характеристика іоновидільної фрункції нирок у щурів з 46-денним алоксаніндукованим експериментальним цукровим діабетом $(\mathrm{X} \pm \mathrm{Sx})$

\begin{tabular}{|c|c|c|}
\hline \multirow[b]{2}{*}{ Показник } & \multicolumn{2}{|c|}{ Група, кількість тварин } \\
\hline & $\begin{array}{l}\text { контроль } \\
(\mathrm{n}=10)\end{array}$ & $\begin{array}{l}\text { 46-денний алоксановий діабет } \\
\qquad(\mathrm{n}=8)\end{array}$ \\
\hline Концентрація іонів натрію в сечі, ммоль/л & $0,56 \pm 0,06$ & $\begin{array}{c}1,12 \pm 0,16 \\
p<0,01\end{array}$ \\
\hline Екскреція іонів натрію, мкмоль на 2 год & $1,74 \pm 0,11$ & $\begin{array}{c}3,99 \pm 0,57 \\
p<0,001\end{array}$ \\
\hline $\begin{array}{l}\text { Стандартизована екскреція іонів натрію, мкмоль/100 мкл } \\
\text { КФ }\end{array}$ & $0,45 \pm 0,05$ & $\begin{array}{l}0,33 \pm 0,05 \\
p>0,1\end{array}$ \\
\hline Фільтраційний заряд натрію, мкмоль/хв & $55,23 \pm 6,02$ & $\begin{array}{c}144,69 \pm 15,26 \\
p<0,001\end{array}$ \\
\hline Відносна реабсорбція іонів натрію, \% & $99,97 \pm 0,003$ & $\begin{array}{c}99,98 \pm 0,004 \\
p>0,3\end{array}$ \\
\hline Кліренс іонів натрію, мл на 2 год & $0,014 \pm 0,001$ & $\begin{array}{l}0,035 \pm 0,005 \\
p<0,001\end{array}$ \\
\hline Концентрація іонів калію в сечі, ммоль/л & $9,90 \pm 0,74$ & $\begin{array}{c}11,63 \pm 0,97 \\
p>0,2\end{array}$ \\
\hline Екскреція іонів калію, мкмоль на 2 год & $31,44 \pm 1,75$ & $\begin{array}{c}41,63 \pm 3,61 \\
p<0,05\end{array}$ \\
\hline $\begin{array}{l}\text { Коесріцієнт співвідношення концентрацій іонів натрію і } \\
\text { калію в сечі, од. }\end{array}$ & $0,057 \pm 0,005$ & $\begin{array}{c}0,100 \pm 0,014 \\
p<0,01\end{array}$ \\
\hline
\end{tabular}

Примітка. Оцінювали міжгрупові відмінності за допомогою непараметричного критерію Манна - Уїтні; р - вірогідність розбіжності показників відносно контролю.

Таблиця 3. Характеристика канальцевого надходження іонів натрію у щурів із 46-денним алоксаніндукованим експериментальним діабетом (X士Sx)

\begin{tabular}{l|c|c}
\hline \multicolumn{1}{c|}{ Показник } & \multicolumn{2}{|c}{ Група, кількість тварин } \\
\cline { 2 - 3 } & $\begin{array}{c}\text { контроль } \\
(\mathrm{n}=10)\end{array}$ & $\begin{array}{c}46-\text { денний алоксановий діабет } \\
(\mathrm{n}=8)\end{array}$ \\
\hline Проксимальна реабсорбція іонів натрію, ммоль на 2 год & $6,20 \pm 0,69$ & $\begin{array}{c}16,96 \pm 1,82 \\
\mathrm{p}<0,001\end{array}$ \\
\hline Дистальне надходження іонів натрію, мкмоль на 2 год & $424,08 \pm 31,99$ & $\begin{array}{c}403,22 \pm 18,03 \\
\mathrm{p}>0,9\end{array}$ \\
\hline $\begin{array}{l}\text { Проксимальна реабсорбція іонів натрію, } \\
\text { мкмоль/100 мкл КФ }\end{array}$ & $12,07 \pm 0,18$ & $\begin{array}{c}11,03 \pm 0,27 \\
\mathrm{p}<0,01\end{array}$ \\
\hline Дистальне надходження іонів натрію, мкмоль/100 мкл КФ & $0,85 \pm 0,03$ & $0,28 \pm 0,02$ \\
& & $\mathrm{p}<0,001$ \\
\hline
\end{tabular}

Примітка. Оцінювання міжгрупових відмінностей за допомогою непараметричного критерію Манна - Уїтні; р - вірогідність розбіжності показників відносно контролю.

\section{висновки}

Хронічна алоксаніндукована гіперглікемія спричиняє розвиток тубулоінтенстиційних порушень, прояви яких спостерігаються задовго до маніфрестації гломерулопатії. Викликане гіпеперфузійно-гіперфрільтраційним перевантаженням нирок виснаження реабсорбційної потужності канальцевого апарату нирок відображається як на проксимальних, так і на 
дистальних канальцях, та ініціює порушення процесів реабсорбції та іоноурез. Саме розлади канальцевого надходження іонів натрію та калію, перерозподіл їх вмісту між судинним, тубулярним та інтерстиційним компартментами нирок, призводять до порушення місцевої гемодинаміки у нирках, зміни гідрофрільності та осмолярності інтерстицію, обмеження регулюючого впливу поворотно-множильної

\section{СПИСОК ЛІТЕРАТУРИ}

1. Шамхалова М. Ш., Факторы тубулоинтерстициального поражения почек при сахарном диабете / М. Ш. Шамхалова, К. О. Курумова, М. В. Шестакова // Сах. диабет. - 2009. - № 4. - С. 61-65.

2. Гавалешко В. П. Механізми порушень фрункціонального та морфологічного стану нирок при цукровому діабеті / В. П. Гавалешко // Клін. та експеримент. патол. - 2015. - № 4(54). - С. 198-202.

3. Бондарь И. А. Тубулоинтерстициальный фииброз при диабетической нефропатии: механизмы развития и подходы к лечению / И. А. Бондарь, В.В.Климонтов // Сах. диабет. - 2008. - № 2. - С. 11-15.

4. Клеточные механизмы фрормирования тубулоинтерстициальных изменений при первичных гломерулопатиях/ В. В. Савош, Т. А. Летковская, Е. Д. Черствый, А. В. Сукало// Мед журн. - 2007. - № 4. - С. 98-100.

5. Rodriguez-Iturbe $B$. Tubulointerstitial damage and progression of renal failure / B. Rodriguez-Iturbe, R. J. Johnson, A. J. Herrera-Acosta // Kidney Int. - 2009. Vol. 68 (99). - P. 82-86.

6. Арутюнов Г. П., Оценка почечной фрункции, степени поражения клубочкового аппарата и тубулоинтерстициальной ткани почек у больных с гипертонической

\section{REFERENCES}

1. Shamkhalova MSh, Kurumova KO, Shestakova MV. [Factors of tubulointerstitial lesions in diabetic kidneys]. Sakh diabet. 2009;4: 61-5. Russian.

2. Havaleshko VP. [Mechanisms of disorders of the functional and morphological condition of kidneys in case of diabetes mellitus]. Klin ta eksperym patol. 2015;4(54): 198202. Ukrainian.

3. Bondar IA, Klimontov VV. [Tubulointerstitial fibrosis in diabetic nephropathy: mechanisms of development and approaches to treatment]. Sakh diabet. 2008;2: 11-5. Russian.

4. Savosh VV, Letkovskaya TA, Cherstvyy ED, SukaloAV. [Cellular mechanisms of formation of tubulointerstitial changes in primary glomerulopathies]. Med zhurn. 2007;4: 98-100. Russian.

5. Rodriguez-Iturbe B, Johnson RJ, Herrera-Acosta AJ. Tubulointerstitial damage and progression of renal failure. Kidney Int. 2009;68(99): 82-6.

6. Arutyunov GP, Oganezova LG, Sokolova A.V. [Assessment of renal function, the degree of damage of the glomerular apparatus and tubulointerstitial tissue of the kidneys in patients with essential hypertension]. Klinich nefrologiya. 2011;6: 16-24. Russian.

7. Borodulin VB, Protopopov AA, Goremykin VI, Utts IA, Shevchenko OV, Volkov AS, Bychkov EN, Losev OE, Nesterenko OV. Diagnostika khronicheskoy bolezni pochek na системи нирок, порушення механізмів концентрування сечі та системи регуляції водно-осмотичної рівноваги. Подальший розвиток клубочково-канальцевого та канальцево-канальцевого дисбалансу, пригнічення альдостерон- та вазопресинзалежних механізмів регуляції осмолярності інтерстицію сприятимуть вторинному ураженню канальців та інтерстицію нирок, прогресуванню ренопатії.

болезнью / Г. П. Арутюнов Л. Г. Оганезова, А. В. Соколова // Клинич/ несррол. - 2011. - № 6. - С. 16-24.

7. Диагностика хронической болезни почек на ранней стадии / В. Б. Бородулин, А. А. Протопопов, В. И. Горемыкин [и др.] // Клинич. нефрол. - 2014. № 2. - C. 52-55.

8. Treatment targets in renal fibrosis / P. Boor, K. Sebeková, T. Ostendorf, J. Floege // Nephrol. Dial. Transplant. - 2007. - Vol. 22. - P. 407-391. DOI: 10.1093/ndt/gfm393.

9. Кришталь МВ, Гоженко Al, Сірман ВМ. Патофрізіологія нирок: навч. посіб. Одеса: Фенікс, 2020. 144с.

10. Шюк О. Функциональное исследование почек / О. Шюк. - Прага : Авиценум, 1981. - 344 с.

11. Сучасні методики експериментальних та клінічних досліджень центральної науково-дослідної лабораторії Буковинської державної медичної академії : навч.метод. посіб. / В. М. Магаляс, А. О. Міхєєв, Ю. Є. Роговий [та ін.]. - Чернівці : Буковинська державна медична академія, 2001. - 42 с.

12. Реброва О. Ю. Статистический анализ медицинских данных. Применение пакета прикладных программ STATISTICA / O. Ю. Реброва. - М. : МедиаСфрера, 2002. -312 c.

ranney stadii [Early diagnosis of chronic kidney disease] Klinich nefrologiya. 2014;2: 52-5. Russian.

8. Boor P, Sebeková K, Ostendorf T, Floege J. Treatment targets in renal fibrosis. Nephrol Dial Transplant. 2007;22: 407-391. DOI: 10.1093/ndt/gfm393.

9. Kryshtal MV, Hozhenko Al, Sirman VM. Pathophysiology of the kidneys: navch. posib. [Патофрізіологія нирок: навч. посіб.] Odesa: Feniks; 2020. Ukrainian.

10. Shyuk O. Examination of kidney function. [Функциональное исследование почек] Praga: Avitsenum; 1981. Russian.

11. Mahalias VM, Mikhieiev AO, Rohovyi YuYe, Shcherbinina AV, Turchynets TH, Chipko TM. Modern methods of experimental and clinical studies of the central research laboratory of Bukovinian State Medical Academy. [Сучасні методики експериментальних та клінічних досліджень центральної науково-дослідної лабораторії Буковинської державної медичної академії: навч.-метод. посіб.] Chernivtsi: Bukovynska derzhavna medychna akademiia; 2001. Ukranian.

12. Rebrova OYu. Statistical analysis of medical data. Application of the STATISTICA software package. [Статистический анализ медицинских данных. Применение пакета прикладных программ STATISTICA]. Moscow: MediaSfera; 2002. Russian.

Отримано 09.02.21 